\title{
Writing from Home: Clarice Lispector's Chronicles in the Jornal do Brasil
}

CLAUDIA DARRIGRANDI NAVARRO

Universidad Adolfo Ibáñez

\begin{abstract}
This article focuses on Clarice Lispector's chronicles published in the Jornal do Brasil from 1967-1973. These chronicles become a public space for exposing the act of thinking, which is strongly linked to emotions, instead of depicting a daily overview of events for the newspaper's readers. Drawing from Bruno Latour's notions of "translation" and "purification," I argue that there is a "translation" process in Lispector's chronicles that goes against "purification practices." To this effect, I focus on how Lispector displays both her thinking process and her emotions, and on the role of things and people in her writing. Lispector delves into life from her home, an environment that becomes an "epistemological space," as defined by Stacy Alaimo.
\end{abstract}

Keywords: Specialization, thing power, actants, daily press, writing

It is well known that Clarice Lispector wrote her 1967-1973 chronicles for the newspaper Jornal do Brasil from home. ${ }^{1}$ From there, Lispector created some of the most unusual chronicles of the second half of the twentieth century. In fact, a great number of her writings for the Jornal do Brasil are about herself, her thoughts, and her feelings. This makes her a unique chronicler, one that challenges what is expected of chronicles, a genre typically dealing with subjects

\footnotetext{
${ }^{1}$ This research has been carried out within the framework of Fondecyt Project No. 11140881 (2014-2017), of which I was the main researcher.
} 
of public interest for a broad readership. Instead of focusing on such topics as urban life, social customs, or arts, Lispector decides instead to delve into how and what she thinks and feels regarding them. Bruno Latour's notions of "translation" and "purification" are useful to discuss Lispector's resistance to specialization; her chronicles manifest a "translation" process and a resistance to "purification practices" (Latour, We Have Never Been Modern). Reconsidering Lispector's contributions to the Jornal do Brasil by examining how the environment impacts her writings, I suggest reading this space, filled with things and people, as an "epistemological space," as defined by Stacy Alaimo. Following Alaimo's ideas, it is possible to understand Lispector's "corporeal substance [...] inseparable from the environment." Her home thus becomes an "epistemological space" where the writer's "corporeality" is transformed into a "transcorporeality [that] reveals the interchanges and interconnections between human corporeality and the more-than-human" (Alaimo n/p).

\section{The Chronicle and Specialization}

In her 1971 crônica “Ao correr da máquina,” Lispector wrote:

Agora vou interromper um pouco para atender o homem que veio concertar o toca-discos. Não sei com que disposição voltarei à máquina ... Pronto, já voltei. O dia continua muito bonito. Mas a vida está muito cara (isso por causa do preço que o homem pediu pelo conserto) ... Eu queria um emprego de poucas horas por dia, digamos duas ou três horas, e que me fizesse (o emprego) lidar com pessoas. Tenho jeito para isso, embora pareça um pouco ausente às vezes ... Se vocês pensam que vou recopiar o que estou escrevendo ou corrigir este texto, estão enganados. Vai é assim mesmo . . A Agora vou interromper para acender um cigarro. Talvez volte à máquina ou talvez pare por aqui mesmo. Voltei. Estou agora pensando em tartarugas. $(341)^{2}$

\footnotetext{
${ }^{2}$ This account of what she does and does not do while writing is rather frequent. She closes another chronicle by stating: "Vou terminar agora porque tenho um espaço determinado neste jornal. Vou ler um pouco. Sobre diamantes. Numa revista italiana que diz . .." (“Sem título" 355-56).
} 
In this quote, Lispector exposes both the material conditions and experience of her writing process. From another point of view, she also exposes chroniclewriting as a practice. Her body expresses itself through emotions, movements, and thoughts. As Rosana Governatory has pointed out, Lispector creates a "new" chronicle, an anti-chronicle, whereby she exposes her intimacies to her readers. I would add that she also exposes her thinking - closely attached to her emotions - in what, for the readers of the Jornal do Brasil, might appear to be a raw manner. ${ }^{3}$ While she writes, while she works, she portrays her writing process as strongly linked to daily domestic tasks as well as to her emotions.

While the office or the newspaper office become privileged spaces in particular after Fordism, Lispector stays at home, as a political stance, making public her private/domestic labor. There is therefore a political statement on her part from the very beginning of her contributions to the Jornal do Brasil. As she writes at home, her writing is surrounded by housekeepers, cigarettes, coffee, memories, letters or phone calls from readers, and her beloved typewriter. In thinking of this scenario, we might recall Jane Bennett's term "thing power," described as "the curious ability of inanimate things to animate, to act, to produce effects dramatic and subtle" (6). In that sense, we might understand her newspaper writings as a result of this power that "arises from bodies inorganic as well as organic" (6). To some extent, all matter in Lispector's environment can be considered an actant, which according to Latour "is something that acts or to which activity is granted by others. It implies no special motivation of human individual actors, nor of humans in general. An actant can literally be anything provided it is granted to be the source of an action" ("On Actor-Network Theory" 373). Bennett clarifies this concept pointing out that "[a]n actant is neither an object nor a subject but an 'intervener,' akin to the Deleuzean 'quasicasual operator"' (9). In Lispector's quote above, the typewriter, the cigarettes, the lighter, the record player, the technician, etc., all of them participate in the chronicle's production. More compellingly, as we read her chronicles, we realize the place that things have for her in her daily life. Lispector writes from home, creating a setting for her work that, at the same time, is constantly being displayed in her writings. Her readers, then, read chronicles about how she becomes a

\footnotetext{
${ }^{3}$ As Debra Castillo points out, it seems that cryptic nature of her writings was one of the reasons why Lispector had to leave her position at the Jornal do Brasil.
} 
chronicler within an "epistemological space," where Lispector's entire body interchanges and interconnects with her environment. Writing from this space allows her to create a new type of chronicle where things and objects gain significant roles, dismantling traditional hierarchies ordering the relationships between things and people.

It is also important to note that Lispector creates this space considering the tension that arises between her writing process, her chronicles, and the discourses about literary and journalistic genres. One of Latour's major hypotheses in We Have Never Been Modern revolves around the word "modern." He proposes that:

[it] designates sets of entirely different practices which must remain distinct if they are to remain effective . . The first set of practices, by 'translation,' creates mixtures between entirely new types of beings, hybrids of nature and culture. The second, by 'purification,' creates two entirely distinct ontological zones: that of human beings on the one hand: that of the nonhumans on the other hand. (10)

Latour also associates "translation" with the word network (and also with mediation); a translation process creates networks that link the natural world with the social and with discourse. ${ }^{4} \mathrm{He}$ also explains that "[purification] made [translation] possible: the more we forbid ourselves to conceive of hybrids, the more possible their interbreeding becomes - such is the paradox of the modern" (11). Hence, I argue that Latour's notions of "translation" and "purification" allow new reflections around Lispector's chronicles, as they help understand them both as a genre and as a practice. In terms of genre, it is well-known that the word chronicle, within the Latin American context, refers to a genre that mingles literary and journalistic discourses; it is a hybrid genre. At the same time, her chronicles exhibit connections between human and non-human worlds. There is an important number of her chroniclers where she displays how things that belong to her environment affect her writing; therefore, understanding the chronicle as a practice also helps see the links between the natural world, the social, and discourse.

\footnotetext{
${ }^{4}$ In Reassembling the Social, Latour chooses to use the term network instead of translation.
} 
During the end of the sixties and early seventies the newspaper Jornal do Brasil was already one of the most widely read newspapers in Brazil, and it was also a "modern" newspaper: content was classified and organized into different sections ("Politics," "Science," "Arts," "Sports," etc.), as in the case of many other newspapers in the Americas. This organization explains, to some extent, the purification process, in Latour's terminology. These categories demonstrate a human will to break down knowledge and activities. Therefore, while the newspaper was designed and diagramed following certain categories, it could not easily fit chronicles into these categories. Chronicles, as we all know, have no specific topic; instead, they are characterized by their flexibility: a chronicle can be written almost about anything. Chronicles circulate in magazines and newspapers, and, because they are such a flexible genre, readers can expect to find them in various different sections: "Feminine Pages," "Entertainment," "Arts," "Social Life," etc. However, unless you were reading the "Feminine Pages," you would not expect to find in chronicles domestic topics or very personal issues and/or information about a chronicler's private environment or intimate life. Before Lispector's writing showed up in the Jornal do Brasil, chronicles had typically focused on public life, urban life, politics, economics, crime, sports, international relations, civil conflicts, culture, entertainment, and all those themes that we might consider public or of public concern. With Lispector the focus of chronicle-writing shifted to daily domestic tasks, personal conflicts, and intimate thoughts.

Lispector, recognizing her lack of expertise at writing chronicles, creates a chronicle that places life at its center, as Méndez has pointed out. In doing so, her writings might be considered the result of a translation practice, the opposite of a purification practice in modern society, following Latour's ideas. Within articles or reportage, translation practice proves to be a continuum. In the first chapter of his book, Latour explains that oftentimes "the same article mixes together chemical reactions and political reactions" revealing how "heads of state, chemists, biologists, desperate patients, and industrialists find themselves caught up in a single uncertain story mixing biology and society" (We Have Never Been Modern 1-2). While we might understand newspapers' will for organization as a purification practice, in the case of chronicles written for a newspaper, we observe a double-sided practice. On the one hand, the chronicle has a special status; it becomes a privileged translation space. It might even be 
seen as a space that resists purification. On the other hand, it could also be a space suitable for specialization and for the professionalization of writers and journalists, as it allows some of them to write about arts and humanities, whereas others might prefer to write about sports or delve into politics, for example.

Within this broad space, Lispector still did not write about what was expected of her, she did not write about one special topic (i.e. cinema, culture, urban life, etc.), she wrote about something larger, like life itself, from a place that was not "pure." Her home, like her chronicles, reveals the human and the non-human engaged in an explicit exchange, one affecting the other. The existing gap between a well-organized (to some extent purified) newspaper and a hybrid flexible genre like the crônica might help understand Lispector's complaints about being unequipped for writing chronicles. As has already been stated, although she wrote for the Jornal to make a living, Lispector resisted understanding the chronicle as a reified object, a journalistic product, and, at the same time, she refused to become a specialized journalist.

Regarding the previously cited quote from "Ao correr da máquina," I would also like to highlight her insistence on displaying herself as a thinker. This practice that can be understood as a strategy to reveal her intellectual mode of production might also be read as a strategy for foregrounding her role as writer. Although Lispector wrote crônicas, the connections of her chronicles to essaywriting are undeniable. Liliana Weinberg discusses the relationship between the thinking process and the writing of an essay, and she states: "an essay represents through writing our thinking process." ("Ensayo y humanismo" 61). Lispector always called these writings crônicas; however, Weinberg's quote allows me to stress that the term, usually linked to information about an event, disguises, at first sight, a thinking process, which Weinberg ties to essay-writing. While publishing in Caderno B, a supplement published every Saturday by the Jornal do Brasil, Clarice used to complain (or pretended to do so) about her lack of competence for writing chronicles. As Mariela Méndez discusses, Lispector began working in journalism with no economic or cultural capital, and she was always expressing her doubts about the genre. Méndez attributes Lispector's discomfort in writing chronicles to the writer's perception that doing so meant exposing herself to readers (93-96). However, Méndez also highlights that Lispector wrote whatever she wanted and that she "transformed the act of writing as well as the act of living into some sort of performance" (96). Therefore, within 
my argument, exposing herself means that she displays her life, her thoughts, and her emotions within a particular environment.

It is also worth emphasizing the fact that Lispector distances herself from the role of the professional journalist or writer during a decade (the late sixties) when Latin American writers are strongly involved in political debates and are playing prominent roles as intellectuals. In "Ao correr da máquina," for instance, she positions herself as something other than a journalist in an editorial office; likewise, she does not see herself as an intellectual who writes in his or her studio, surrounded by books and other literary materials. This is an interesting choice on her part. Lispector chooses to place herself at home working for a newspaper, and this gesture says quite a bit about her stance regarding her work. There is a new meaning attached to home, as it is her workplace: it is not only the place of reproductive duties but also productive ones, she is a journalist, a chronicler, who writes from home with her typewriter on her lap.

The first day that Lispector wrote for Caderno B, on August 19, 1967, she contributed four "pieces" that considered a wide range of topics. While she thinks of Yuri Gagarin, she exposes her own reflections about astronomy, technology, and science ("Cosmonauta na terra" 24-25). She also writes about a child and her mother having a hard time on account of the little boy starving ("As crianças chatas" 23), and about the experience of looking at oneself in a mirror ("A surpresa" 23). In her compelling chronicle "Brincar de pensar" (23-24), she blends thoughts and emotions, and she manages to highlight her own experience. Tania Genetic has studied this singular approach to thinking and to knowledge, pointing out that Lispector's chronicles "theorize the knowing subject as at once within and beyond the linguistic structures of power that uphold the Brazilian government. They do so by presenting and affective notion of knowledge distinct from that circumscribed by the nation-state" $(140) .{ }^{5}$ With regard to this idea, it is worth noting that the following week her writing focuses on two women's meetings ("Tanto esforço" 26), and on the relationship between death and nature (“O processo" 26-27). In both chronicles, Lispector examines women's knowledge as well as female bonding, while highlighting women's daily life struggles and wondering about the meaning of life. Therefore, these chronicles

\footnotetext{
${ }^{5}$ In the chapter "Knowledge Beyond Borders," Gentic delves into knowledge problematization and emotions in the chronicles Lispector published in Jornal do Brasil. She focuses on the formation of reading communities and the political scope of her writing.
} 
leave aside issues related to the nation-state to give space instead to these other minor concerns.

The writer moves freely from one topic to another, and there is no clear structure. Some of her chronicles are very short; others are long and sometimes look like short stories. She even defies one of her colleagues because in this space that lacks specialization, she realizes that she has an expertise that makes her a singular chronicler: "desafio você, Armando Nogueira, a perder o pudor e escrever sobre a vida e você mesmo, o que significaria a mesma coisa," she writes in "Armando Nogueira, futebol e eu, coitada" (89-91). In this chronicle, she establishes a dialogue with Armando Nogueira, who has become an expert in writing chronicles about soccer. Lispector challenges him to write about what soccer means to him so that this might help show readers what he "sente em relação à vida" (91). Her critique of Nogueira's specialization is significant to understand her stance about her own job as a contributor for Jornal do Brasil. If Noguera writes about one topic (soccer), Lispector's chronicles, in contrast, are about a wide array of subjects. Such a broad agenda clashes with the newspaper's contents, which are classified and organized neatly into sections and pages. In other words, her writing goes against the will of most professional press culture, her chronicles occupy an uncomfortable position within this medium.

In "Ao correr da máquina," quoted at the very beginning of this article, Lispector's writing practice is situated within an environment where human bodies circulate (she and the man who repairs her record player) bringing into the scene movements and gestures (she comes to and goes away from the typewriter) as well as opinions and thoughts. At the same time, she also warns that something could happen to her writing because of the technician's interruption: "Não sei com que disposição voltarei à máquina," writes Lispector ("Ao correr da máquina" 341). This gesture sets up front, intentionally or not, the spontaneity underlying her chronicle-writing. It also highlights the intervention of the actants that participate in that scenario; there are not only humans, there are objects too: a record player, a typewriter, and cigarettes. Lispector writes surrounded by actants that not only inform her chronicles but also affect them. There is a second interruption, when she lights a cigarette, and once she is back, she is thinking of something totally different about her environment, the content of her writing or her recent actions.

In these chronicles, sometimes writing becomes a task that is much more 
material than intellectual. Her body moves, she leaves the typewriter, then she is back again to it. It resembles a sort of talk show, the reader follows her actions and movements as if it were a live program. Nevertheless, when the intellectual realm appears, when she focuses on ideas instead of telling what is happening at her place, Lispector becomes deeply engaged with it and it takes over life, as these lines demonstrate: "O que eu quero contar e tão delicado quanto a própria vida" ("A descoberta do mundo" 113). A similar gesture occurs when she states that "Sou uma pessoa muito ocupada: tomo conta do mundo" ("Eu tomo conta do mundo" 275). These chronicles then become a sort of detailed diary, where her writing is "unpolished," as she embraces her distractions and disapproves of rewriting or proofreading.

In summary, I would like to highlight that she writes somewhere in her home instead of doing so in an office. This is a first sign that she resists a professional take on her job. Her home and herself are the core of her chronicles; this fact leads to chronicles whose main subject matter is "life." On the one hand, this is another manner whereby she defies specialization. On the other hand, in doing so, her "home" becomes an "epistemological" space, in Alaimo's terms, where she practices becoming a chronicler. Body, mind, emotions, as well as human and more-than human actants are blended, as the quote from "Ao correr da máquina" shows. This quote clearly represents Lispector's orientations towards her work, towards her house, towards her writing. It is her entire body that is committed to her writing, a body affected by all of the interruptions and all the actants that surround her, which will in turn affect writing. This all emphasizes Lispector's resistance to both late capitalism and modern journalism. In considering a great part of her chronicles published in the Jornal, it is possible to see that Lispector dismantles the chronicle as a commodity. The writer removes the notion of news or information about city life and replaces that with her perception of people or city events, writing about them from a very personal and private point of view and sometimes even replacing these subjects with her own thoughts and her feelings. There is no information regarding city novelties, for example, but a description of how her writing occurs, and of her train of thought regarding a city event or piece of news. In the following pages, I will focus on the "epistemological space," in particular, on objects and people as actants that participate in Lispector's writing practice. 


\section{Pen, Flowers, and Perfumes}

Both the environment and the objects surrounding the writer at home have a role. I want to foreground that her approach to things and matter is connected to the exposure of her thoughts and feelings. At the climax of industrialization and the division of labor after Brazilian desenvolvimento, I argue that Lispector has a holistic appreciation of life and work that makes her work a clear manifestation of resistance against capitalism, at least in her chronicles. It is life, where organic and non-organic elements share spaces and environments, that is at the core of her writings for the newspaper, and in this regard there are no hierarchies between humans and non-humans, or human bodies and other bodies, or public versus private, etc. In her chronicle "Máquina escrevendo," Lispector writes: "A máquina continua escrevendo. Por exemplo, ela vai escrever o seguinte ... Agora a máquina vai parar. Até sábado próximo" (348-49). The play of words is interesting here, insofar as the chronicler and the machine become the same figure, stressing the dichotomy between human and object. I would like to propose this union between the chronicler and the typewriter as an example of Alaimo's "transcorporeality," a concept that "underlines the extent to which the corporeal substance of the human is ultimately inseparable from the environment." The wordplay that blends chronicler and typewriter is reiterative and the embodiment of the typewriter gradually gains force in her writing. In one of her last chronicles, Lispector points out: "Escrevendo praticamente a vida toda, a máquina de escrever ganha uma importância enorme. Irrito-me com esta auxiliar ou então agradeço-lhe fazer o papel de reproduzir bem o que sinto: humanizo-a" ("Propaganda de graça" 475). ${ }^{6}$

While in many of her chronicles Lispector accentuates the relationship she has with the typewriter, there is one in particular where the leading role is played by a golden pen, "O caso da caneta de ouro." Concerned with the effects that a pen can produce on her writing, the chronicler asks herself a number of questions and indicates: "E se o jeito [de escrever] mudasse, na certa ele iria, por seu turno, me influenciar - e eu também mudaria. Mas em que sentido?" (56). The quote highlights the sensitivity in understanding that the pen could have an effect on her. In other words, the pen could indeed affect her, and, with that recognition

\footnotetext{
${ }^{6}$ For more on the relationship that Lispector has with her typewriter, see chapter two of Mallea.
} 
comes a reaffirmation of the chronicler's consciousness about the "thing power" that Jane Bennett underlines: using the pen "would also change her." Lispector exposes her vulnerability and reinforces the notion of "transcorporeality" between her and the golden pen, between both of them as "matter" or "substance." In this way, her reflections, which arise from a domestic daily anecdote, are in line with the process Roberto Esposito has described: "Things affect us at least as much as we affect them. Just as things cannot live without us, we cannot live without them" (122, my translation). Upon that first reflection that the chronicler makes about the pen, the matter diverts onto the relationship with her children. Her eldest son's lack of attachment to things does not ever convince her; hence she reproaches him for not paying attention to what is happening at home regarding the pen. Finally, the chronicle concludes with the son rebuking his mother because many times in the past she refused to give him what he asked for, and it concludes with: "a caneta de ouro nos levara longe. Achei melhor parar. E por aí ficamos. Nem sempre esmiuçar demais dá certo" (58). This quote recalls her other chronicle, cited at the beginning of this article, "Brincar de pensar," where she notes that thoughts lead to emotions. The pen plays a much more complex role than merely aiding the author with her writing. The pen permeates her family ties, relationships, domestic harmony, and allows her to discover her eldest son's wound, a wound that leaves her in an uncomfortable situation that she cannot solve in her text. In this chronicle, as in a number of them, many times learning is a task to be accomplished for herself rather than for her readers. Thus, the private tone of her musings is emphasized; at the core of this writing is a very personal matter instead of a topic of public concern. Nevertheless, the writer slips in brief comments that lead readers to infer that the lesson learned from the "pen case" could be useful for them as well.

In other chronicles, the objects acquire a mysterious aspect, carry secrets that the chronicler does not resolve, which implies leaving the reader in doubt. Unable to solve the mystery, the chronicler highlights certain features of the objects that trigger her reflection: "As rosas silvestres têm um mistério dos mais estranhos e delicados: à medida que vão envelhecendo, vão perfumando mais" ("Rosas silvestres" 105). That perfume, according to the chronicler, is the soul, and at the end of the chronicle she indicates that she would like to assimilate to the flower, to become a flower in order to have a death like that of the flower, when the perfume - the soul — gets out with all its intensity. In another of her texts, entitled 
"O suéter," Lispector points out: "É de um vermelho-luz e parece captar tudo o que é bom para ele e para mim. Esta é a sua alma: a cor" (122). At the end of the chronicle, she states: "Terminada esta nota, vou-me perfumar com um perfume que é meu segredo: gosto das coisas secretas" (122). The mysterious tone emphasizes that, although she is exposing herself in the chronicle, there are some secrets of hers that the reader will not be able to discover, secrets that are closely attached to her relationship with things. Similar ideas are presented in her chronicle entitled "Os perfumes da terra." This chronicle reinforces the idea that aromas convey identity: "E eu me perfumo para intensificar o que sou" ("Os perfumes da terra" 132), whereby she assimilates herself to earth and nature, breaking down the distance between nature and culture. The chronicler creates herself as a "new type of being," following Latour's notion of translation, built out of nature and culture. Here, again, senses have a special place and sensing is a means to become nature, because she wants to be like the earth, "perfumada" (132). However, this gesture is also related to a wisdom that, according to the chronicler, comes from instincts. Thus, she introduces a survival feature that if, on the one hand, animalizes her, on the other, blends her and nature in complete harmony. Later, she introduces again the notion of perfume and secrecy: "Que perfume usarei? Acho que já sei qual. Não digo que perfumes eu uso: são o meu segredo" ("Sem título" 355). I would like to emphasize here the perfume's immateriality; Lispector's secrets are, to some extent, almost impossible for the reader to infer from the chronicle. She does not describe aromas, she keeps them to herself. In other words, she does not only avoid sharing the name of an aroma but she also keeps away any information of how an aroma smells. A similar gesture happens when she writes about flowers, enhancing in both cases the image of a chronicler who, despite exposing herself every Saturday on the pages of Caderno B, is still a mystery. There is a soul that is exposed and impenetrable at the same time.

The sweater, the flower, the perfume, either on account of their soul or of their secrets, affect her writing or affect the exposure of the self to the readers. I would like to recall Alaimo's ideas about the relation between the human and the "more-than-human:" “"nature' is always as close as one's own skin. Indeed, thinking across bodies may catalyze the recognition that the 'environment,' which is too often imagined as inert, empty space or as a 'resource' for human use, is, in fact, a world of fleshy beings, with their own needs, claims, and 
actions" ("Trans-corporeal"). It thus becomes necessary to highlight that the transcorporeality of which Alaimo speaks closely resembles the translation process introduced by Latour. Although Latour points out that translation and purification practices go hand in hand, in Lispector's writing translation practices acquire another meaning, as they unsettle a trade, a genre, and a production method as molded by chroniclers such as Rubem Braga, Fernando Sabino or Armando Nogueira, whom Lispector invokes, recalls or mentions in her chronicles. Lispector exposes her work and exposes herself as a writer, a chronicler, a mother, a housewife; that is, she exposes herself by fulfilling multiple iterations. In the same way, while daily life seems at times to invade and interrupt her writing, these interruptions are ultimately the key distinctive elements of her chronicles.

\section{Sharing the Work Environment: Lispector Writing about Maids}

While writing from home, Lispector can take charge of the world, and immerse herself in thought about nature and the secrets of life; it is also in this space that she has to mingle with domestic aides. In Domestic Servants in Literature and Testimony in Brazil (1889-1999), Sônia Roncador dedicates a chapter to the study of domestic workers in Lispector's writing, and states that their presence in her texts allowed her to reconcile the contradiction that emerged between her image as a defender of the oppressed (remember those were the dictatorship years) and her privileged position (138).

Domestic workers are part of that environment, of that ecosystem wherein the chronicle is produced: "Aninha é uma mineira calada que trabalha aqui em casa. . . Raramente fala," is how the chronicle "A mineira calada" begins (47). Lispector then focuses on introducing Aninha to her readers. However, she changes her name to Aparecida because "ela é uma aparição muda" (47). Until that moment, Aninha is just an image, almost on the edge of the ghostly, the ethereal, and the immaterial. That is to say, in contrast to the typewriter, the pen, the flowers, among other multiple objects and things that surround the chronicler, Aninha is almost air. At the same time, like perfume, she is a mystery. When making an appearance, Aninha is also a nuisance, and so is writing chronicles. After the introduction, the chronicle proceeds to recount a conversation that the narrator and the maid hold about Lispector's writing, a situation that definitely 
annoys the chronicler. While she embroiders and the woman cleans in silence, the latter bursts in on the chronicler. In a "continuation of silence"-a Lispectorian oxymoron-Aninha asks to confirm that the person she works for is a writer and indicates that she wants to borrow a book of hers. The writer, for her part, decides not to lend her a book, because she underestimates the maid's reading comprehension skills, to which Aninha replies: "Gosto de coisas complicadas. Não gosto de agua com açúcar" (“A mineira calada" 48). It is an interesting reaction on the part of the writer, as if she wanted to protect her work environment, which she does not want to share with Aninha. Although she writes chronicles, which might appear to be easy reading, when Aninha refers to her books, this means for Lispector crossing a boundary into the literary realm. Both work in the same place: one is doing house chores, the other one is writing. One is working for the other one. Lispector tries to keep Aninha outside her own work turf. This scene serves to illustrate Lispector's "homemade journalism;" her work and home chores converge into one same space: the writing of chronicles.

The writer senses a threat to her space, her territory. From her perspective, Aninha tries to access the world of literature, to know that perhaps it does not belong to her, and the cronista tries to cast her out. On the other end, Aninha tries to locate herself in a more visible, less servile, and more intellectual place, as if she were aware of the ghostly condition to which she is subjected by the chronicler's pen. Aninha, then, through words, tries to materialize, to be a valid material interlocutor for Lispector. The chronicle ends there, with the expression of that desire for complicated things as expressed by Aninha. So, Aninha is an unexpected actant that intervenes in Lispector's writing in two ways: she occupies the space where Lispector writes and she also becomes part of the chronicle. That very same day, in the same newspaper, Lispector publishes another brief chronicle, which focuses on Jandira ("A vidente" 48). Jandira is the cook and a clairvoyant, "forte. Tão forte que é vidente" ("A vidente" 48). The contrast with Aninha is powerful. Jandira, who is endowed with another gift, another source of knowledge, is presented in opposition to the ghostly Aninha. The scenario is the same, the house. However, this time the cook appeals to the chronicler's sister, who came to visit, which unleashes tension in the chronicle. Appearing suddenly and shrouded in silence, Aninha surprises the chronicler with previously unsuspected desires and qualities: she is not silent, she speaks to her, and she is also a reader of complex subjects. Jandira, on the other hand, by 
seeing what others cannot, takes control of the chronicle by displacing the chronicler, to the extent that she has access to privileged information that the chronicler does not have about her sister's life. The two maids challenge Lispector and have powerful consequences on her work environment, a work environment that is shared by all three of them, out of which might arise a power struggle: "Both the cook and the cleaning woman arouse confusion in Lispector; the two have both capabilities and knowledge that encroach into the chronicler's territory" (Darrigrandi 104). These domestic issues seem to be irrelevant themes for a chronicle that is not published on the women's page. While Lispector is intent on exposing how she deals with her work as writer, it is the relation mastermaid and her discomfort that comes to the center of the chronicle. As I mentioned in the first section of this article, in these chronicles, emotions, household chores and disputes take the place of information or news about city events.

Therefore, people, like objects, threaten domestic harmony, as they are both strongly intertwined with the chronicler. Nonetheless, Lispector resists "human power" much more strongly than she does "thing power." Days later, in her chronicle "Por detrás da devoção," the silent miner, Aninha, unexpectedly "puxa conversa" and "é renitente" (49). Aninha's spectral body turns dynamic, what was once an appearance ceases to be "continued silence" and acquires more body, more matter. In the chronicler's words, Aninha "se transformou. Como se desenvolve aqui em casa! Até puxa conversa, e a voz agora é muito mais clara" ("Por detrás da devoção" 49). The story of Aninha turns into a lesson for the reader by way of recommendations that show how one should engage with domestic service. The summary would be as follows: the employee, at first mute, gradually develops and acquires confidence; when her unexpected speech becomes a threat, as she asks to read a book authored by the housewife, the latter silences her handing her instead a police novel (probably because, for the chronicler, this is more suitable reading in light of the maid's social condition). However, the chronicler's suggestion ends up being a failure because Aninha is not satisfied with that offer. In the case of Jandira, the discomfort that the chronicler feels towards domestic service becomes accentuated by religious wisdom. Jandira advises and explains things to her boss that the latter cannot understand, and Lispector highlights this issue by recalling the disturbing play by Genet entitled Maids, and a few more stories about other employees she has had in the past. In the end, the chronicler feels guilty for exploiting them. 
In "Das doçuras de Deus," Aninha's story comes to an end. Lispector addresses her readers by pointing out: "Vocês já se esqueceram da minha empregada Aninha, a mineira calada ... Vocês a esqueceram. Eu nunca a esquecerei. Nem sua voz abafada, nem os dentes que lhe faltavam na frente e que por instância nossa botou, à toa: não se viam porque ela falava para dentro e seu sorriso também era mais para dentro. Esqueci de dizer que Aninha era muito feia" (53). In this quote, on the one hand, Lispector perhaps suggests the reflections of someone who works at home could indeed be insignificant and uninteresting. On the other hand, she challenges her audience to read something that was not common on the pages of a massive, commercial newspaper. In this chronicle, Lispector reconstructs Aninha's story and insists on remembering previous chronicles so that her readers can understand everything Aninha has gone through. However, the chronicle points out something new for the audience: "para ela existir como pessoa, dependia muito de se gostar dela" ("Das doçuras de Deus" 53). After a territorial dispute with the maids, Lispector gets back to emotions and to dismissing all the intellectual features that Aninha displayed while working at her home.

Gentic indicates that Lispector's chronicles build "a community of subjects who can be thought as beyond that of the nation-state, as she repackages political issues through a filter of affective subjectivity that makes knowledge of the self into an intersubjective activity" (141). Aninha, Jandira, and Lispector's affection towards them make it possible for Lispector to know more about herself as well as about her maids; likewise, her maids have a strong insight into who their master is. While they exchange words, perceptions and thoughts, Aninha and Jandira make the chronicler aware of other sources of knowledge that she does not own. Their exchange also reveals that both Jandira and Aninha have a sort of supernatural skill that challenges Lispector's intellectual and cultural capital. Aninha and Jandira affect Lispector's writing as the gold pen would. Both the gold pen and the maids have the power to disturb and nurture the chronicler's work. The chronicler cannot control these other materials even though she is the master and the author of the chronicles; they sneak into her writing creating a space intervened both by human and non-human participants. This workspace, therefore, becomes a sui generis one, a "transcorporeal one" where intellectual, emotional, and domestic issues play equal roles. 


\section{Closing Remarks}

If we go back to Lispector's chronicle "Eu tomo conta do mundo," and remember the writer attempting to accomplish the tremendous task of devoting her life and work to the world, or if we recall her political stance in sharing with readers her own life, a life, nonetheless, in which we all live, we notice how she presents herself as a subject who exaggerates its self-construction. With that task in mind, she can hardly separate thought from emotion or herself from the environment. Objects, flowers, perfumes, pens, kids, visitors, domestic servants, each of these plays a role in her chronicles, although none of them plays the leading role, because they are all "actants" (Latour), they do express a "thing power" (Bennett). Lispector is totally aware of the power of all these objects affecting her life and her writings. Therefore, her chronicles belong to a writing practice that challenges a "purification process," in Latour's terms. Lispector exposes her thoughts, her emotions, and her body oriented towards her environment, an environment full of actants that affect her body, movements, thoughts, and emotions. In the end, "humans" and "more-than humans" affect her writing as a material experience. Writing from home becomes a "translation process," as defined by Latour, because she delves into life from a holistic point of view. The impact of her work environment on her writing transforms her chronicles into a type of writing that challenges work specialization in two ways. On the one hand, she is not a specialist writing chronicles nor is she known as a chronicler who writes on one specific topic; on the other hand, it is somewhat difficult to ascribe these writings to one literary or journalistic genre.

\section{Works Cited}

Alaimo, Stacy. "Trans-corporeal Feminisms and the Ethical Space of Nature." Material Feminisms, edited by Stacy Alaimo and Susan Hekman, Indiana UP, 2008.

Bennett, Jane. Vibrant Matter: A Political Ecology of Things. Duke UP, 2010.

Castillo, Debra. "Lispector, cronista." Clarice Lispector: novos aportes críticos, edited by Cristina Ferreira Pinto and Regina Zilberman, Instituto Internacional de Literatura Iberoamericana, 2007, pp. 95-108.

Darrigrandi Navarro, Claudia. "Exposición y reflexión en la escritura de Clarice 
Lispector en el Jornal do Brasil.” Mapocho, vol. 81, 2017, pp. 94-107.

Esposito, Roberto. Las personas y las cosas. Katz, 2016.

Gentic, Tania. The Everyday Atlantic: Time, Knowledge, and Subjectivity in the

Twentieth-Century Iberian and Latin American Newspaper Chronicle. State U of New York P, 2013.

Governatory, Rosana. "Identidad y escritura en crónicas de mujeres latinoamericanas: Clarice Lispector.” Espéculo, vol. 51, 2013, pp. 101-18.

Latour, Bruno. "On Actor-Network Theory: A Few Clarifications." Soziale Welt, vol. 47, no. 4, 1996, pp. 369-81.

-. Reassembling the Social: An Introduction to Actor-Network Theory. Oxford UP, 2005.

- We Have Never Been Modern. Translated by Catherine Porter, Harvard UP, 1993.

Lispector, Clarice. "A descoberta do mundo." A descoberta do mundo. Rocco, 1984, pp. 113-15.

—. "A mineira calada." A descoberta do mundo. Rocco, 1984, pp. 47-48.

- " "A surpresa." A descoberta do mundo. Rocco, 1984, p. 23.

—. "A vidente." A descoberta do mundo. Rocco, 1984, p. 48.

—. "Ao correr da máquina." A descoberta do mundo. Rocco, 1984, pp. 340-42.

—. "Armando Nogueira, o futebol e eu, coitada." A descoberta do mundo. Rocco, 1984, pp. 89-91.

—. "As crianças chatas." A descoberta do mundo. Rocco, 1984, p. 23.

—. "Brincar de pensar." A descoberta do mundo. Rocco, 1984, pp. 23-24.

—. "Cosmonauta na terra." A descoberta do mundo. Rocco, 1984, pp. 24-25.

—. "Das doçuras de Deus." A descoberta do mundo. Rocco, 1984, pp. 53-55.

—. "Eu tomo conta do mundo," A descoberta do mundo. Rocco, 1984, pp. 27576.

—. "Intelectual? Não.” A descoberta do mundo. Rocco, 1984, p. 49.

—. "Máquina escrevendo." A descoberta do mundo. Rocco, 1984, pp. 347-49.

—. "O caso da caneta de ouro." A descoberta do mundo. Rocco, 1984, pp. 5558.

—. "O processo." A descoberta do mundo. Rocco, 1984, pp. 26-27.

—. "O suéter." A descoberta do mundo. Rocco, 1984, p. 122.

—. "Os perfumes da terra." A descoberta do mundo. Rocco, 1984, pp. 132-33.

—. "Por detrás da devoção." A descoberta do mundo. Rocco, 1984, pp. 49-51. 
—. "Propaganda de graça." A descoberta do mundo. A descoberta do mundo. Rocco, 1984, pp. 475-76.

—. "Rosas silvestres." A descoberta do mundo. Rocco, 1984, p. 105.

—. "Sem título." A descoberta do mundo. Rocco, 1984, pp. 354-56.

—. "Tanto esforço." A descoberta do mundo. Rocco, 1984, p. 26.

Mallea, Macarena. Clarice Lispector cronista: autofiguración, estilo y tecnología en algunas crónicas publicadas en el Jornal do Brasil (19671973). 2018. U de Chile. MA tesis, repositorio.uchile.cl/handle/2250/ 171011.

Méndez, Mariela. Crónicas travestis: el periodismo transgresor de Alfonsina Storni, Clarice Lispector y María Moreno. Beatriz Viterbo, 2017.

Roncador, Sônia. Domestic Servants in Literature and Testimony in Brazil, 18891999. Palgrave McMillan, 2014.

Weinberg, Liliana. "Ensayo y humanismo." Co-herencia, vol. 10, no. 20, 2014, pp. 59-79. 